\title{
139 プラント状態監視のための忘却付き再帰的最小二乗法の改良
}

Improved Recursive Least Squares with forgetting for Plant Monitoring

\author{
○正 田村 雅之（東京ガス）
}

Masayuki Tamura, Tokyo Gas Co., Ltd., Suehiro-cho 1-7-7, Tsurumi-ku, Yokohama-shi, Kanagawa

\begin{abstract}
An improved algorithm of recursive least squares (RLS) is presented. In order to prevent wind-up of RLS with exponential forgetting caused by lack of persistently excitation, various methods have been proposed in the past. One of the most popular methods is RLS with variable forgetting factor which regulates trace of covariance matrix to be constant. This paper proposes an improvement of the algorithm which avoids a problem of the conventional method on model instability which arises when d.c. bias of input signal is slowly varying, which is a common case of plant monitoring applications in systems affected by ambient temperature and/or humidity varying considerably slowly compared to plant dynamics.
\end{abstract}

Key Words: Fault detection, Fault diagnosis, Recursive Least Squares, System Identification

\section{A1.はじめに}

忘却付きの再帰的最小二乗法 (Recursive Least Squares: RLS）によってプラントモデルの逐次同定を行い、推定さ れたパラメタのトレンドを参考にプラントの状態監視をす ることを考える。その際、入力変数が励起不十分となった 場合のモデル不安定性を回避するための手法として本研究 では共分散行列の跡を一定とするアプローチに着目する。 従来提案されている、変数の DC 成分を除去してから固定 トレース法による忘却定数の決定を行う方法では、変数の DC 成分が緩慢に変化する場合に同定精度が劣化するとい う問題があった。多くのプラントにおいて、プラントのダ イナミクス（秒、分の程度）と比較して緩慢な動き（日の 程度）をする気温や湿度を回㷌モデルに含む必要があるた め、本研究ではこの点に注目し、モデルをより安定化させ るための改良法を提案する。

\section{A2. 手法}

$$
y(t)=\theta^{T}(t) \phi(t)+e(t)
$$

で表されるシステムについて、次式のような一般的によく 知られた RLS アルゴリズムを適用する。

$$
\begin{aligned}
& \left.\hat{\theta}(t)=\hat{\theta}(t-1)+K(t) \mid y(t)-\hat{\theta}^{T}(t-1) \phi(t)\right] \\
& K(t)=P(t) \phi(t) \\
& P(t)=\left[I-\frac{P(t-1) \phi(t) \phi^{T}(t)}{\lambda+\phi^{T}(t) P(t-1) \phi(t)}\right] \frac{P(t-1)}{\lambda}
\end{aligned}
$$

このとき、従来の固定トレース法では

$$
\begin{aligned}
& \hat{u}_{D C}(t)=\lambda_{u} \hat{u}_{D C}(t-1)+\left(1-\lambda_{u}\right) u(t) \\
& \hat{y}_{D C}(t)=\lambda_{y} \hat{y}_{D C}(t-1)+\left(1-\lambda_{y}\right) y(t)
\end{aligned}
$$

$$
\lambda(t)=1-\left[r(t)-\left\{r^{2}(t)-4 \frac{\|P(t-1) \phi(t)\|^{2}}{\operatorname{tr} P(t-1)}\right\}^{1 / 2}\right] / 2 \cdots
$$

のように忘却定数を決め、式(A2)を適用するが、本研究で は DC 成分除去を行わずに入力ベクトル $\phi(t)$ の第 1 成分に定 数項を含めた上で

$$
\begin{aligned}
& \mathbf{q}(t)=\left[q_{1}(t), q_{2}(t), \cdots, q_{m+1}(t)\right]^{T}=P(t-1) \phi(t) \\
& \mathbf{s}_{u}(t)=\left[q_{2}(t), \cdots, q_{m+1}(t)\right]^{T} \\
& \lambda(t)=1-\left[r(t)-\left\{r^{2}(t)-4 \frac{\left\|\mathbf{s}_{u}(t)\right\|^{2}}{\operatorname{tr} P(t-1)-P_{11}(t-1)}\right\}^{1 / 2}\right] / 2
\end{aligned}
$$

のように忘却定数を決めることを提案する。

式(A6)に表す簡単な数值例によって提案手法を評価した ところ、Table Al のように、提案手法はそれぞれのパラメ 夕 $\left(\theta_{0}\right.$ および $\left.\theta_{1}\right)$ について全ての場合で最良とは限らな いものの、全体として良い性能を示していることが分かっ た。

$$
\begin{aligned}
& u_{1}=N(0,1), \quad u_{2}=\sin \left(\frac{\pi t}{2200}\right)+1 \\
& y=\theta_{0}+\theta_{1} u_{1}-\theta_{2} u_{2}+e \quad(e=N(0,0.5)) \\
& \text { Fault }: \quad \theta_{0}: 10 \rightarrow 6 \quad \theta_{1}: 0.9 \rightarrow 0.7
\end{aligned}
$$

Table Al Comparison of methods

\begin{tabular}{|c|l|c|c|c|}
\hline \multirow{2}{*}{} & & \multicolumn{2}{|c|}{ Conventional } & \multirow{2}{*}{ Proposed (\%) } \\
\cline { 3 - 5 } & & RLS (\%) & Fixed trace (\%) & \\
\hline \multirow{2}{*}{$\theta_{0}$} & False Negative & 1.93 & 0.52 & 0.49 \\
\cline { 2 - 5 } & False Positive & 1.63 & 0.22 & 0.24 \\
\hline \multirow{2}{*}{$\theta_{l}$} & False Negative & 0.34 & 9.2 & 1.62 \\
\cline { 2 - 5 } & False Positive & 0.21 & 3.6 & 0.64 \\
\hline
\end{tabular}

によって DC 成分を推定し、データから除去した後に 


\section{1.はじめに}

設備の安定稼働および高効率稼働を確保するために、プ ラント状態の適切な把握とそのトレンド監視を行うことが 重要である。一つの方法として、設備の各種計測変数間に 成立する関係を理論的もしくは経験的な回帰式の形で表し、 計測されるデータから逐次そのパラメタを推定してプラン トの状態を知る手がかりとすることが考えられる。一例を 挙げれば、ガスタービン発電システムにおける発電性能の 監視においては、燃料投入量等の制御変数や、外気温度等 の環境変数々発電量の関倸を監視すべきであり、線形近似 可能な運転範囲であればこれらを入出力変数とした回帰モ デルを利用することが考えられる。

上記の目的で、忘却付きの再帰的最小二乗法（Recursive Least Squares: RLS) によってモデルのオンライン同定を行 い推定されたモデルパラメタのトレンドを監視すること を考える。その際、入力変数による励起が不十分となった 場合にモデルが不安定となることが古くから知られており、 不安定性を回避するために、忘却定数を時変とする方法 (1)-(3)や、過去の情報のうち新しく観測されたデータに影響 を受ける部分のみを忘却する Directional Forgetting ${ }^{(4)}$ 等の方 法が提案されている。

本研究では過去に知られている手法の中で、共分散行列 の跡を一定とするように忘却定数を変化させる方法 ${ }^{(2)}$ (以 下、固定トレース法と呼ぶ）に注目する。過去に、測定デ 一タから DC 成分を取り除いてから固定トレース法を適用 することが提案されているが、この方法では、変数の DC 成分が緩慢に変化する場合に同定精度が劣化するという問 題があった。多くのプラントにおいて、プラントのダイナ ミクス（秒、分の程度）と比較して緩慢な動き（日の程度） をする気温や湿度を回帰モデルに含む必要があるため、入 力変数に緩慢な変化が含まれることは不可避である。本研 究ではこの点に注目し、モデルをより安定化させるための 改良法を提案する。具体的には、各変数について直流成分 の除去をせずに RLS を行い、共分散行列から一部の成分を 除いた部分行列のトレースを固定することを提案する。

\section{2. 課題設定}

プラントの状態は、温度や湿度といった環境の影響を受 けることが多い。それらの変数はプラントの種類にもよる が、各種プラント変数と比較してゆっくりとした時間変化 であることが多い。Fig. 1 に、実在するコジェネレーション プラントにおける負荷の実績值と気温の変化、負荷制御に 使用されるある制御変数の動きを示す。この例では、プラ ントの制御は秒単位かそれ以下で行われる一方、気温は日 単位の低い周波数で変動している。今の場合、負荷と制御 変数、気温の間に相関があることがわかっており、制御の 異常を早期に発見するためのモデルとして、負荷と気温の 両者を入力とし、制御变数を出力とした回帰モデルを作成 するとよいことがわかっている。Fig. 1 のデータについて RLS によって回帰モデルのパラメタの一つを逐次同定した
結果の一部が Fig. 2 である。この間、プラントは無故障状 態であったので、このパラメタは 25〜35 程度の值をとると 経験的に予想された。ところが、65〜70 時間付近において 負荷がほとんど一定となったことに起因してRLS のパラメ 夕推定結果は不安定となり、15２0 という非現実的な値を とった。この計算上の問題を回避した固定トレース法（従 来法）の適用結果を Fig. 3 に示しているが、65～70 時間付 近の不安定性は解消されているものの、今度は 45 50 時間 付近において若干ではあるがパラメタが不安定となって急 速に振動している。この間、このような急速なパラメタ変 化は物理的に考えづらい状態であったので、これは別の計 算の不安定性に起因すると考えられる。後述するように、 これは外気温度がゆっくりと変化していることが原因と考 えられる。このような変数の緩慢な変化によるパラメタの 不安定性を改善することが本研究の課題である。
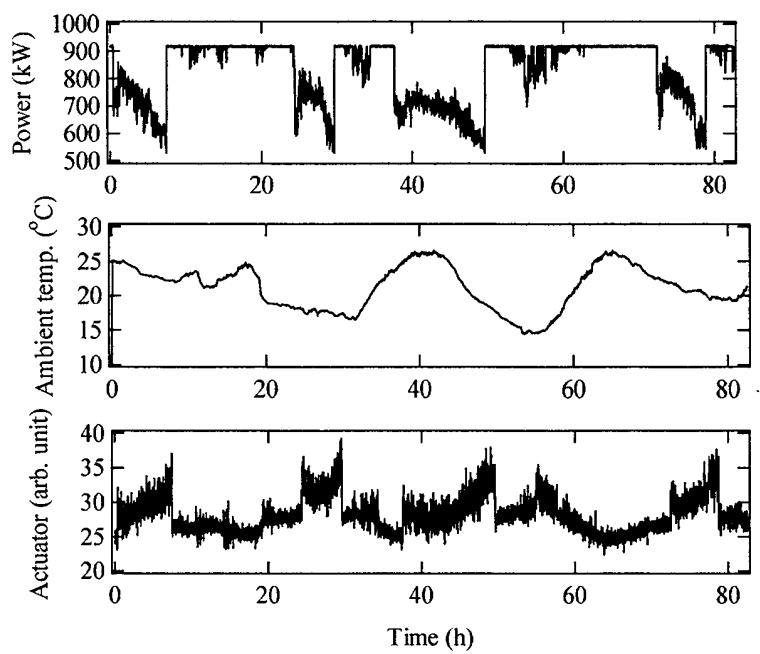

Fig. 1 Data related to an existing co-generation system.

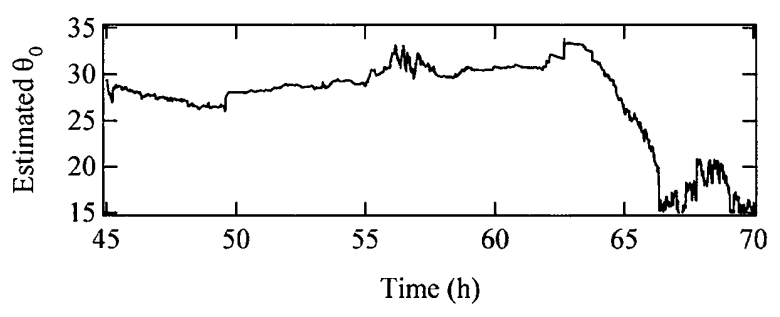

Fig. 2 Parameter estimated by RLS.

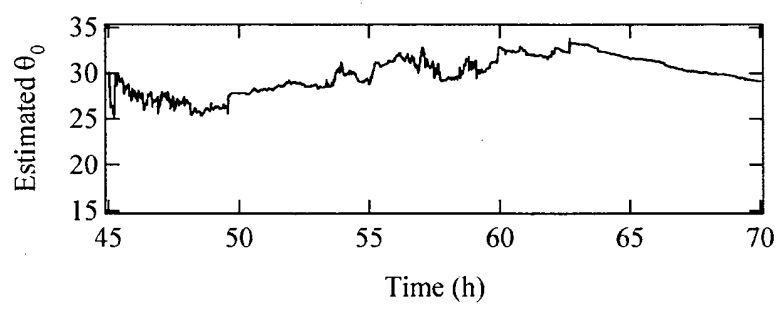

Fig. 3 Parameter estimated by conventional fixed trace method. 


\section{3. 手法}

忘却付き RLSの一般的な形は以下の通りである。入力変 数を $\phi(t)$ 、出力変数を $y(t)$ として、対称となるシステムのモ デルが次の線形回帰式で表されたとする。

$$
y(t)=\theta^{T}(t) \phi(t)+e(t)
$$

ここで $\theta(t)$ はモデルパラメタ、 $e(t)$ は誤差である。 $\phi(t)$ は一 般に過去のある程度の期間の入出力值を含み、(1)式は動的 システムを表現するが、本研究では議論の簡単化のため、 多入力 1 出力の静的システムを扱うものとし、 $\phi(t)=\left[u_{I}(t), u_{2}(t), \ldots, u_{m}(t)\right] 、 \theta(t)=\left[\theta_{l}(t), \theta_{2}(t), \ldots, \theta_{m}(t)\right]$ とする。こ の時、モデルパラメタ $\theta(t)$ が時間に依存しており、設備の劣 化やその他の状態変化によって変わるものとし、これを推 定するための方法として以下の RLS 法が知られている。

$$
\begin{aligned}
& \left.\hat{\theta}(t)=\hat{\theta}(t-1)+K(t) \mid y(t)-\hat{\theta}^{T}(t-1) \phi(t)\right] \\
& K(t)=P(t) \phi(t) \\
& P(t)=\left[I-\frac{P(t-1) \phi(t) \phi^{T}(t)}{\lambda+\phi^{T}(t) P(t-1) \phi(t)}\right] \frac{P(t-1)}{\lambda}
\end{aligned}
$$

ここでגは忘却定数であり、1よりわずかに小さな数が使 用される。 $P(\mathrm{t})$ は共分散行列と呼ばれ、通常初期值として単 位行列の定数倍（定数は大きな数）が使用される。

入によって過去のデータの情報を忘却しながらパラメタ を更新していく際に生ずる、従来から知られている問題点 として、新しいサンプルの分布がいわゆる励起不足となっ た場合、 $P(\mathrm{t})$ が発散してモデルが不安定となることが挙げら れる。例えば $\phi(\mathrm{t})$ の成分が全て 0 となった場合、(2)の第 3 式より $P(\mathrm{t})$ が無限大に発散することは容易に理解できる。 この問題点を解決するために、時変忘却定数を用いる方法 を始め、いくつかの手法が提案されている。本研究では、 $P(\mathrm{t})$ のトレースを一定に保つように時変忌却定数 $\lambda(\mathrm{t})$ を定め る固定トレース法と、その改良提案について以下に述べる。

\section{$3=1$ 従来法 : 固定トレース法(2)(3)}

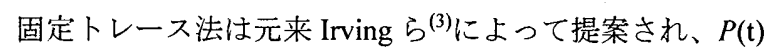
のトレースを一定に保つように時変忘却定数 $\lambda(\mathrm{t})$ を定める ことで $P(\mathrm{t})$ の発散を防止するものである。(2)の第 3 式にお いて両辺のトレースをとり、 $P(\mathrm{t})=P(\mathrm{t}-1)$ とおくことによって 以下の関係式を得る。

$$
\lambda(t)=1-\left[r(t)-\left\{r^{2}(t)-4 \frac{\|P(t-1) \phi(t)\|^{2}}{\operatorname{tr} P(t-1)}\right\}^{1 / 2}\right] / 2
$$

ただし $r(\mathrm{t})=1+\phi^{\mathrm{T}}(\mathrm{t}) P(\mathrm{t}-1) \phi(\mathrm{t})$ である。Sripada らの提案した手 順 (2)では、式(3)を使用する前に以下の指数忘却フィルタに
よって入出力の DC バイアスを推定し、除去する。

$$
\begin{aligned}
& \hat{u}_{D C}(t)=\lambda_{u} \hat{u}_{D C}(t-1)+\left(1-\lambda_{u}\right) u(t) \\
& \hat{y}_{D C}(t)=\lambda_{y} \hat{y}_{D C}(t-1)+\left(1-\lambda_{y}\right) y(t)
\end{aligned}
$$

この方法は、信号のバイアスが一定であり、高い周波数の ノイズが顕著である場合に有効であると指摘されており、 緩慢に変化する DC 成分を有する場合には(4)式の $\lambda_{\mathrm{u}} 、 \lambda_{\mathrm{y}}$ を 慎重に選ぶ必要があるとされている(2)。

\section{$3 \cdot 2$ 提案手法}

各変数について DC 成分の除去を行わずに、入力变数を $\phi(t)=\left[1, u_{l}(t), u_{2}(t), \ldots, u_{m}(t)\right] 、 モ テ ゙ ル ハ ゚ ラ メ タ を ~ \theta(t)=\left[\theta_{0}(t)\right.$, $\left.\theta_{I}(t), \theta_{2}(t), \ldots, \theta_{m}(t)\right]$ のうに定義し、(1),(2)式による RLS を行 う。この方法は従来から良く知られている DC 成分をパラ メタの一つとして同定する手法である。その際、時変忘却 定数 $\lambda(\mathrm{t})$ を次のように算出寸る。

$$
\begin{aligned}
& \mathbf{q}(t)=\left[q_{1}(t), q_{2}(t), \cdots, q_{m+1}(t)\right]^{T}=P(t-1) \phi(t) \\
& \mathbf{s}_{u}(t)=\left[q_{1}(t), \cdots, q_{m+1}(t)\right]^{r} \\
& \lambda(t)=1-\left[r(t)-\left\{r^{2}(t)-4 \frac{\left\|\mathbf{s}_{u}(t)\right\|^{2}}{\operatorname{tr} P(t-1)-P_{11}(t-1)}\right\}^{1 / 2}\right] / 2
\end{aligned}
$$

すなわち、行列 $P(\mathrm{t})$ の第 $(1,1)$ 成分をのぞくトレースを一定 とするように $\lambda(\mathrm{t})$ を決める。この提案手法によって $P(\mathrm{t})$ の発 散が防止できることについて、本報告末尾の Appendix に証 明を記載する。

\section{4. 数值例}

\section{$4 \cdot 1$ 例題とするシステム}

本研究では、回帰の入力変数の一つとして緩やかな時間 変化をするものがある場合に忘却付き RLS を使用すること の問題点を検討するために、以下の式で表されるシステム を考える。

$$
\begin{aligned}
& u_{1}=N(0,1), \quad u_{2}=\sin \left(\frac{\pi t}{2200}\right)+1 \\
& y=10+0.9 u_{1}-0.7 u_{2}+e \quad(e=N(0,0.5))
\end{aligned}
$$

Fig. 4 に計算例を示すように、 $u_{2}$ の変動周波数は $u_{1}$ と比 較して析違いに遅い。Fig. 4 の例では、時刻 3000 と 5000 に おいて故障が起こったと仮定している。その故障はそれぞ れ、式(6)の第三式右辺において第一項の変化と第二項の係 数の変化で表され、それぞれ次の式で表されるシステムに 変化したとしている。すなわち、 $\theta_{0}$ が時刻 3000 において 10 から 6 に $\theta_{1}$ が時刻 5000 において 0.9 から 0.7 に変化し たとする。 


$$
\begin{aligned}
& y=10+0.9 u_{1}-0.7 u_{2}+e \quad(0 \leq t<3000) \\
& y=6+0.9 u_{1}-0.7 u_{2}+e \quad(3000 \leq t<5000) \\
& y=6+0.7 u_{1}-0.7 u_{2}+e \quad(5000 \leq t)
\end{aligned}
$$
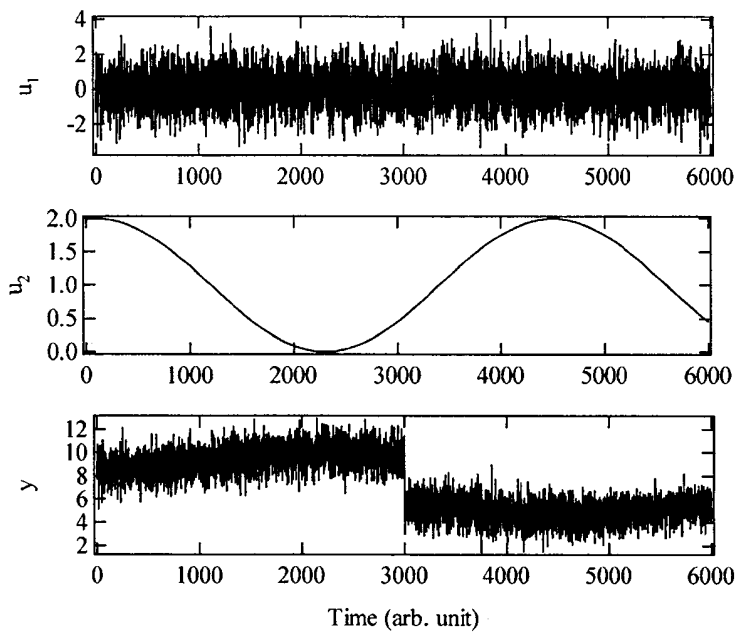

Fig. 4 Data generated from a system described in Eq. 5.

\section{$4 \cdot 2$ 結果}

以下、一般的な RLS、従来の固定トレース法を採用した RLS、さらにそれを改良した本研究の提案手法の比較を行 う。Fig.4のデータを式(4)で表される指数移動平均フィルタ によって処理して DC 成分を求め、元のデータから差し引 くことによって得た DC 成分除去後のデータを RLS および 従来の固定トレース法に使用した。このとき、 $\lambda_{\mathrm{u}}=\lambda_{\mathrm{y}}=0.99$ とした。

(5)の第 3 式の各パラメ夕 $\left(\theta_{0}=10 \rightarrow 6, \theta_{1}=0.9 \rightarrow 0.7, \theta\right.$ ${ }_{2}=0.7$ ）を各手法によって同定した結果を以下 Fig. 5〜7 に 示す。
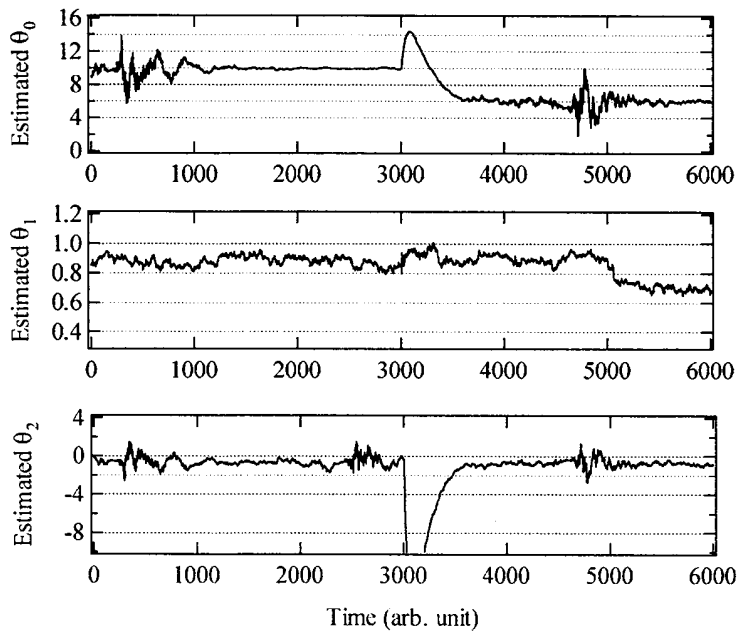

Fig. 5 Model parameters identified by RLS.
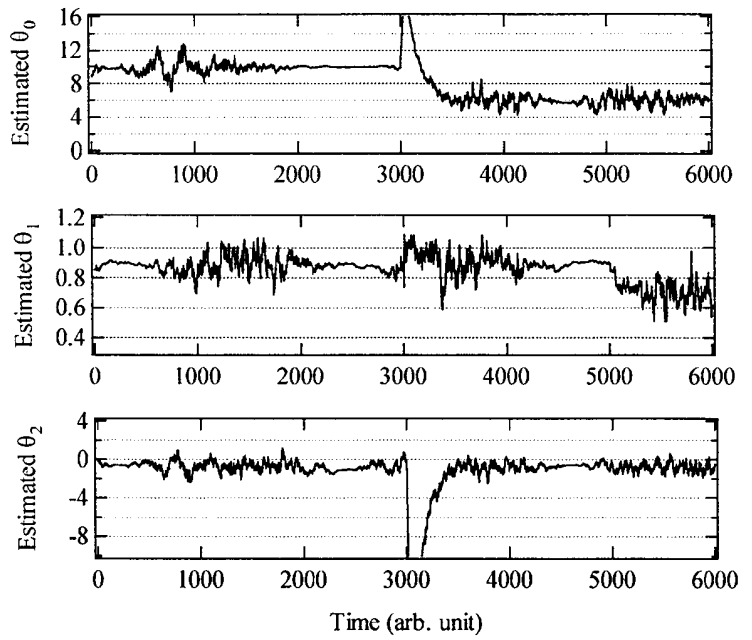

Fig. 6 Model parameters identified by conventional fixed-trace RLS.
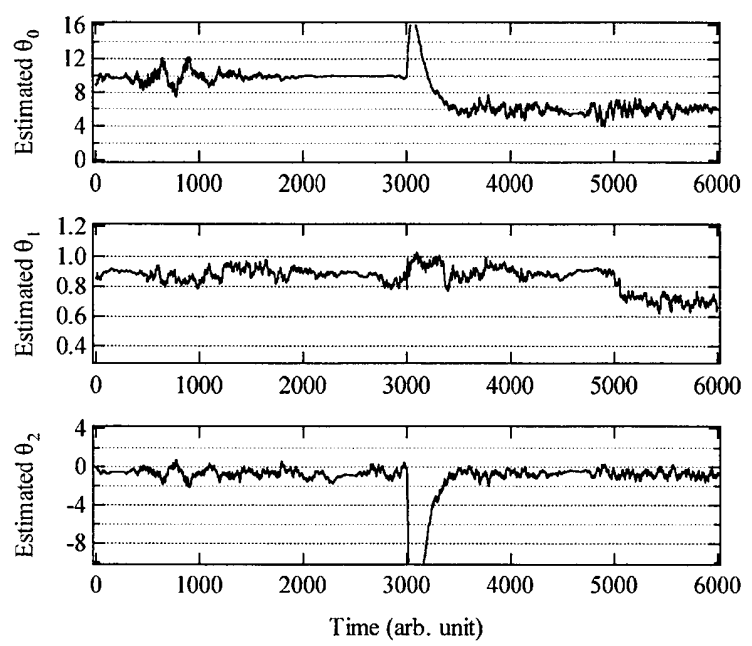

Fig. 7 Model parameters identified by proposed method.

Fig. 5 によれば、RLS の結果は200、2500、4700 点目をや やすぎたあたりで不安定となっている。これは、データの 忘却の結果、 $u_{2}$ の極大、極小值を過ぎた付近でサンプルデ 一夕の分散が小さくなり、励起不十分となって (2)式の $P(t)$ が増大して不安定となったものである。一方で、Fig. 6 を見 ると、従来の固定トレース法においては 1500、3500、5500 点目の前後にパラメタが不安定となっている。これについ ては DC 成分の緩慢な変化に由来すると考えられ、詳細は 節を改好考察する。Fig. 7 を見ると、提案手法はRLSの 励起不十分の問題による不安定性も無く、従来の固定トレ 一ス法のデータの不安定性も無い。安定しているときの RLS に比べるとややパラメタが不安定なところもあるが、 総合的に見て 3000 点目と 5000 点目のそれぞれの変化が捉 えやすく、優れていると言って良い。さらに定量的に故障 検出法としての性能を比較するために、 $\theta_{0}$ および $\theta_{1}$ の変 化を検出寸る䦨值をそれぞれ 8 と 0.8 として、故障状態であ るにもかかわらず警報が発せられないデータの割合（False 
Negative Rate）と正常状態であるにもかかわらず警報が発せ られてしまうデータの割合（False Positive Rate）について、 上記のシミュレーションを100回行って得られた平均值を、 Table 1 に示寸。正常状態は 3000 点目まで、故障状態は各パ

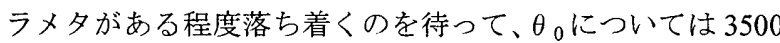
点目以降、 $\theta_{1}$ については 5200 点目以降とした。 $\theta_{0}$ の同定 については、RLS の誤り割合が他と比較して 4～8 倍程度高 く、 $\theta_{1}$ の同定については従来の固定トレース法が誤判定を する割合が 5 倍〜30 倍程度高い。提案手法は $\theta_{0}$ および $\theta$ それぞれのケースで最良ではないものの、全体として良い 性能を示していることがわかる。

Table 1 False negative rates and false positive rates

\begin{tabular}{|c|l|c|c|c|}
\hline \multirow{2}{*}{} & & \multicolumn{2}{|c|}{ Conventional } & \multirow{2}{*}{} \\
\cline { 3 - 5 } & & RLS (\%) & Fixed trace (\%) & \\
\hline \multirow{2}{*}{$\theta_{0}$} & False Negative & 1.93 & 0.52 & 0.49 \\
\cline { 2 - 5 } & False Positive & 1.63 & 0.22 & 0.24 \\
\hline \multirow{2}{*}{$\theta_{1}$} & False Negative & 0.34 & 9.2 & 1.62 \\
\cline { 2 - 5 } & False Positive & 0.21 & 3.6 & 0.64 \\
\hline
\end{tabular}

\section{5. 従来法の不安定性に関する考察}

Fig. 8 に DC 成分除去後の入出力データを示す。 $u_{2}$ につ ては Fig. 4 に示した波形と比較して振幅が小さくなってい るものの（縋軸のスケールが異なることに注意）、元の変数 が緩やかに增減をしているため、式(4)の移動平均フィルタ 適用の結果、元のデータが増加傾向にある場合はプラス側 に、減少傾向にある場合はマイナス側にバイアスが残って しまうことがわかる。処理後にどのような形となるかは式

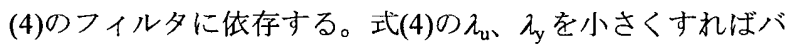
イアスは少なくなるが、ノイズの影響が大きくなり、パラ メタ推定精度が悪化する。このため、緩慢に変化する変数 を扱うとき、 $\lambda_{\mathrm{u}}$ 、 $\lambda_{\mathrm{y}}$ はある程度大きくせざるを得ない。

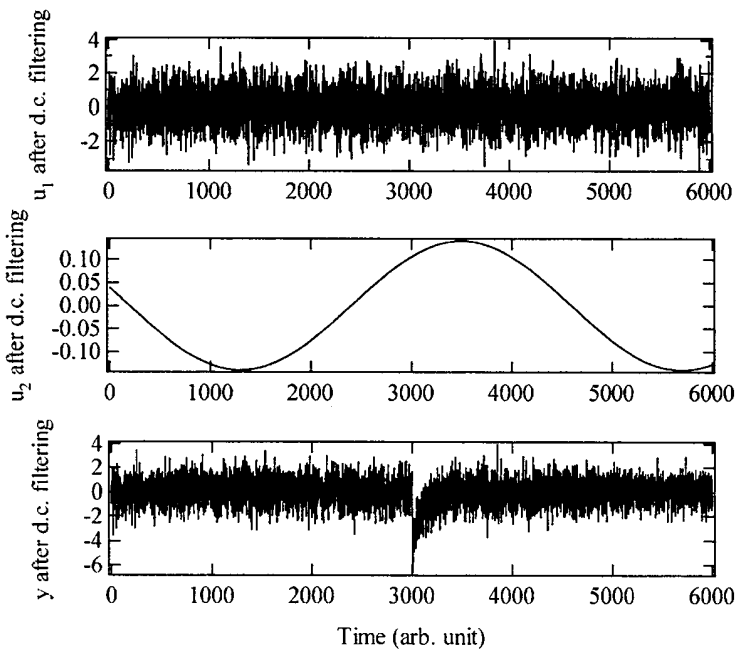

Fig. 8 Data after DC subtractions.
今の場合、結果的に $1500 、 3500 、 5500$ 点目付近において $u_{2}$ にバイアスが存在し、以下の考察から、このことが原因 となって不安定性が見られたと考えられる。

一般に $m$ 個の入力変数がある場合、 $R=P^{-1}$ を考える。入 力 $u_{1}, u_{2}, \ldots, u_{\mathrm{m}}$ は平均值 0 とし、 $\mathrm{j}$ 番目の変数 $u_{\mathrm{j}}$ がバイアス

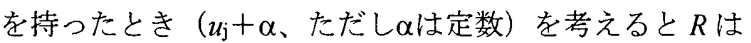

$$
\begin{aligned}
R & =\sum_{1} \lambda \varphi \varphi^{T} \cong\left[\begin{array}{ccc}
\sum_{1} \lambda u_{1}^{2} & \sum \lambda u_{1}\left(u_{j}+\alpha\right) & \\
\sum \lambda u_{1}\left(u_{j}+\alpha\right) & \sum \lambda\left(u_{j}+\alpha\right)^{2} & \\
& & \ddots \sum \lambda u_{m}^{2}
\end{array}\right] \\
& \cong\left[\begin{array}{llll}
\underline{\sum \lambda u_{1}^{2}} & \ddots & \sum \lambda u_{1} u_{j} & \\
\sum \lambda u_{1} u_{j} & \underline{\sum \lambda u_{j}^{2}+\sum \lambda \alpha^{2}} & \\
& & \ddots & \sum \lambda u_{m}^{2}
\end{array}\right]
\end{aligned}
$$

となり、各入力変数間の相関が強くなければ、下線を引い た成分以外は以下の計算で無視できる。式(2)の $P(\mathrm{t})$ を考え るためにまず $R$ の行列式を考えると、

$$
\operatorname{det} R \cong\left(\sum \lambda u_{j}^{2}+\sum \lambda \alpha^{2}\right) \prod_{k \neq j}\left[\sum \lambda u_{k}^{2}\right]
$$

となり、 $\alpha$ に依存して増大する。一方、 $R$ の余因子行列の 対角項を考えると、

$$
\begin{aligned}
& \widetilde{R}_{i i} \cong\left(\sum \lambda u_{j}^{2}+\sum \lambda \alpha^{2}\right) \prod_{k \neq i, j}\left[\sum \lambda u_{k}^{2}\right] \quad(i \neq j) \\
& \widetilde{R}_{j j} \cong \prod_{k \neq j}\left[\sum \lambda u_{k}^{2}\right]
\end{aligned}
$$

よって、バイアス $\alpha$ が存在すると $P\left(=R^{-1}\right)$ の対角項について は、 $P_{\mathrm{ij}}$ が減少、それ以外は $\alpha に$ 依存しないことがわかる。

以上の考察により、従来の固定トレース法の $1500 、 3500$ 、 5500 点目付近においては入力変数のバイアスによって $\mathrm{tr} P$ が減少しようとし、その結果式(3)によって忘却定数が小さ くなり、サンプルの忘却が早くなりすぎるために同定結果 が不安定となったと考えられる。実際、従来の固定トレー ス法と提案手法の忘却定数を比較すると Fig. 9 のようにな っている。一方で、提案手法は Appendix に示すようにデ ータのオフセットの影響を受けないため、安定する。

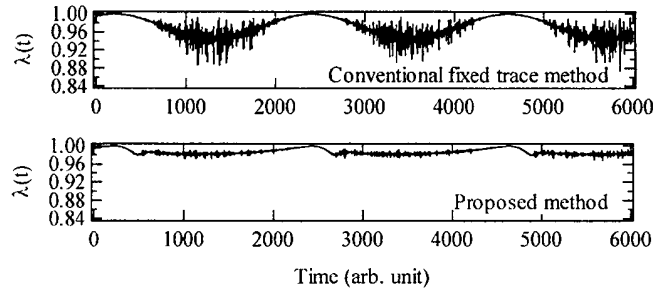

Fig. 9 Forgetting factors. 


\section{6. 実プラントへの適用}

提案手法を実プラントデータに適用した。Fig. 1 のデータ に対する提案手法によるパラメタ推定の結果を Fig. 10 に示 す。まず、Fig. 2、3 と比較すると、65７0 時間付近の RLS の不安定性は従来の固定トレース法同様解消されているこ とがわかる。一方、45～50 時間付近に注目すると、提案手 法は従来の固定トレース法と比較して安定性が改善されて いることがわかる。

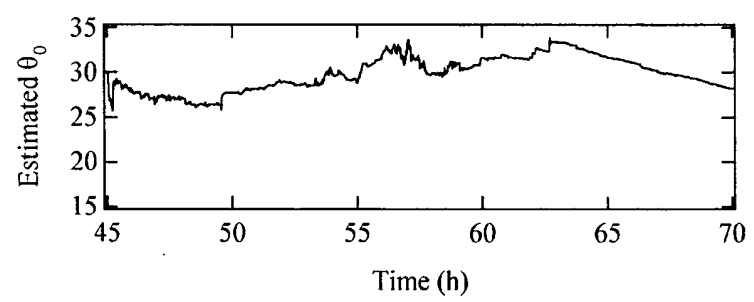

Fig. 10 Parameter estimated by proposed method.

\section{7. まとめ}

設備の状態監視に回帰モデルを利用し、忘却付き RLSに よるオンラインパラメタ同定を行う場合について考察した。 設備は一般に温度や湿度等の影響を受けることが多く、回 帰モデルの変数として採用する必要がある。これらがプラ ント変数よりも相当緩慢な速度で変動する場合、従来提案 されているように変数の DC 成分を除去してから固定トレ 一ス法を適用する方法ではデータの残留バイアスによって モデルが不安定となる場合がある。データに DC 成分を残 したままDCバイアスもパラメタの一つとして直接推定し、 $P$ の特定の要素を除いた対角項の和を一定とするアルゴリ ズムを提案し、上記不安定性が回避されることを示した。 なお本研究では入力変数の一つに DC 成分が加わるケース を検討し、Appendixにもその場合の証明を示した。複数変 数に DC 成分が加わるケースの研究は今後の課題である。

\section{Appendix，提案手法に関する証明}

今、定数項を 1 番目として議論しても一般性を失わない。 簡単のためすべての $u_{\mathrm{i}}$ の平均を 0 とする。 $R\left(=P^{-1}\right)$ は $u_{\mathrm{j}}$ がバ イアスを持ったとき $\left(u_{\mathrm{j}}+\alpha\right.$ 、ただし $\alpha$ は定数 $)$

$$
\begin{aligned}
& R=\sum_{+} \lambda(t) \varphi \varphi^{T} \cong\left[\begin{array}{cccccc}
\sum \lambda & 0 & \cdots & \sum \lambda\left(u_{j}+\alpha\right) & \cdots & 0 \\
0 & \sum \lambda u_{1}{ }^{T} & & \sum \lambda u_{1}\left(u_{j}+\alpha\right) & & \\
\vdots & & \ddots & & & \\
\sum \lambda\left(u_{j}+\alpha\right) & \sum \lambda u_{1}\left(u_{j}+\alpha\right) & & \sum \lambda\left(u_{j}+\alpha\right)^{2} & & \\
\vdots & & & & \ddots & \\
0 & & & & & \sum \lambda u_{m}{ }^{2}
\end{array}\right]
\end{aligned}
$$

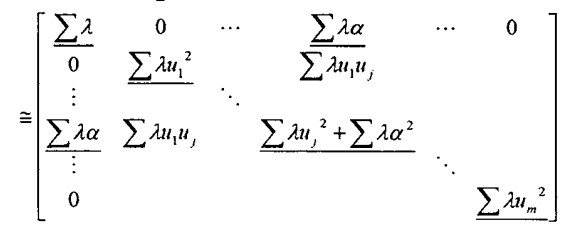

となる。以下断りのない限り、和は時間についてとってい る。また、明示していないが入や $u$ は時間に依存する変数で
ある。今、入力変数間の相関が小さいとすると、アンダー ラインを引いた項（対角項と $R_{1 j}, R_{j 1}$ ）以外は小さく、以下 の計算においては無視して良い。 $R$ の行列式は

$$
\begin{aligned}
\operatorname{det} R & \cong \sum \lambda\left(\sum \lambda \alpha^{2}+\sum \lambda u_{j}^{2}\right) \prod_{k \neq j}\left[\sum \lambda u_{k}^{2}\right]-\left(\sum \lambda \alpha\right)^{2} \prod_{k \neq j}\left[\sum \lambda u_{k}^{2}\right] \\
& =\sum \lambda \prod_{k}\left[\sum \lambda u_{k}^{2}\right]
\end{aligned}
$$

となり、 $\alpha に$ 依存しない。 $R$ の余因子行列の対角項は、

$$
\begin{aligned}
& \widetilde{R}_{11} \equiv\left(\sum \lambda \alpha^{2}+\sum \lambda u_{j}^{2}\right) \prod_{k \neq j}\left[\sum \lambda u_{k}^{2}\right]=\prod_{k}\left[\sum \lambda u_{k}^{2}\right]+\sum \lambda \alpha^{2} \prod_{k \neq j}\left[\lambda u_{k}^{2}\right] \\
& \widetilde{R}_{q q} \equiv \widetilde{R}_{22}=\cdots=\widetilde{R}_{j-1 j-1}=\widetilde{R}_{j+1, j+1} \cdots=\widetilde{R}_{m m} \\
& \cong \sum \lambda\left(\sum \lambda \alpha^{2}+\sum \lambda u_{j}^{2}\right) \prod_{k \neq q-1, j}\left[\sum \lambda u_{k}^{2}\right]-\left(\sum \lambda \alpha\right)^{2} \prod_{k \neq q-1, j}\left[\sum \lambda u_{k}^{2}\right] \\
& =\sum \lambda \prod_{k \neq q-1}\left[\sum \lambda u_{k}^{2}\right] \\
& \widetilde{R}_{j j} \cong \sum \lambda \prod_{k \neq j}\left[\sum \lambda u_{k}^{2}\right]
\end{aligned}
$$

よって、 $R$ の余因子行列の対角項は 11 成分のみが $\alpha の$ 影響 を受けて増大し、その結果 $P\left(=R^{-1}\right)$ の対角項は 11 成分の みが $\alpha$ 影響を受けて増大する。しかしながらその増大は無 限大に発散するわけではなく、有限の值に落ち着くため、 計算の安定性に致命的ではない。一方で、式(12)(13)より、 $p$ 番目の変数の分散が 0 に近づいた場合、式(5)のように 11 成分以外の $P$ の対角項の和を一定とする計算法により

$$
\sum_{k \neq 1} P_{k k}=\sum_{k} \frac{1}{\sum \lambda u_{k}^{2}} \cong \frac{1}{\sum \lambda u_{p}^{2}}
$$

を一定とすることはすなわち、 $\Sigma \lambda u_{p}^{2}$ が一定となるように忘 却定数を調節することになる。このとき $P_{11}$ は

$$
P_{11}=\frac{R_{11}}{\operatorname{det}(R)}=\frac{1}{\sum \lambda}+\frac{\alpha^{2}}{\sum \lambda u_{j}^{2}}
$$

である。功 1 より少し小さな值で推移すれば第 1 項の分母 は 0 にならず、 $\Sigma \lambda u_{j}{ }^{2}>\Sigma \lambda u_{p}{ }^{2}=$ 一定 $(>0)$ なので第 2 項も発散し ない。よって、計算は安定する。

\section{文献}

(1) Fortescue, T., R, L. et. al. (1981) Implementation of Self-tuning Regulators with Variable Forgetting Factors, Automatica, 17, pp. 831-835.

(2) Sripada, N. R. and D. G Fisher (1987) Improved Least Squares Identification, Int. J. Control, 46, pp. 1889-1913.

(3) Irving, E. et. al. (1980) Discrete-time Model Reference Multivariable Adaptive Control Applications to Electrical Power Plants, Lect. Notes in Control \& Inform. Sci., 28, pp. 229-250

(4) Cao, L. and H. M. Schwartz (1999) A Novel Recursive Algorithm for Directional Forgetting, Proc. American Control Conference, pp. 1334-1338. 